\title{
Are there urban signatures in the tropospheric ozone column products derived from satellite measurements?
}

\author{
J. Kar ${ }^{1}$, J. Fishman ${ }^{2}$, J. K. Creilson ${ }^{1,2}$, A. Richter ${ }^{3}$, J. Ziemke ${ }^{4}$, and S. Chandra ${ }^{4}$ \\ ${ }^{1}$ Science Systems and Applications Inc., Hampton, VA, 23666, USA \\ ${ }^{2}$ NASA Langley Research Center, Hampton, VA, 23681, USA \\ ${ }^{3}$ Institute of Environmental Physics, University of Bremen, Bremen, Germany \\ ${ }^{4}$ GEST, University of Maryland, Baltimore, MD, USA
}

Received: 1 December 2009 - Published in Atmos. Chem. Phys. Discuss.: 10 February 2010

Revised: 23 April 2010 - Accepted: 31 May 2010 - Published: 14 June 2010

\begin{abstract}
In view of the proposed geostationary satellite missions to monitor air quality from space, it is important to first assess the capability of the current suite of satellite instruments to provide information on the urban scale pollution. We explore the possibility of detecting urban signatures in the tropospheric column ozone data derived from Total Ozone Mapping Spectrometer (TOMS)/Solar Backscattered Ultraviolet (SBUV) and Ozone Monitoring Instrument (OMI)/Microwave Limb Sounder (MLS) satellite data. We find that distinct isolated plumes of tropospheric ozone near several large and polluted cities around the world may be detected in these data sets. The ozone plumes generally correspond with the tropospheric column $\mathrm{NO}_{2}$ plumes around these cities as observed by the Scanning Imaging Absorption Spectrometer for Atmospheric Chartography (SCIAMACHY) instrument. Similar plumes are also seen in tropospheric mean ozone mixing ratio distribution after accounting for the surface and tropopause pressure variations. The total column ozone retrievals indicate fairly significant sensitivity to the lower troposphere over the polluted land areas, which might help explain these detections. These results indicate that ultraviolet (UV) measurements may, in principle, be able to capture the urban signatures and may have implications for future missions using geostationary satellites.
\end{abstract}

\section{Introduction}

The issue of urban pollution and how it affects the regional and even global environment has become increasingly important in view of the fact that nearly $50 \%$ of the world pop-

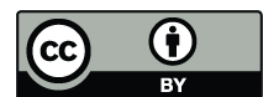

Correspondence to: J. Kar

(jayanta.kar@nasa.gov) ulation is predicted to be concentrated in large urban centers in the near future (Gurjar et al., 2008). Recent modeling efforts indicate that both horizontal transport within the boundary layer as well as vertical lifting of pollution from megacities can be very important for regional scale pollution (Lawrence et al., 2007). A few megacities like Mexico City have been studied extensively in this context using ground based and aircraft campaigns (e.g. Molina et al., 2007), but future monitoring of urban pollution is likely to employ satellite remote sensing, especially if atmospheric composition measurements are made from geostationary platforms (e.g., see discussion in Fishman et al., 2008). In this context, we examine the extent to which enhanced pollution signature of cities can be detected using the currently available satellite observations.

The detection of urban pollution signatures from space is linked to several factors such as the lifetime of the species, the sensitivity of the measurements to the lower troposphere and the vertical profile of the species. In general, the sensitivity to the boundary layer is only modest, $\sim 15-30 \%$ for $\mathrm{UV}\left(\mathrm{O}_{3}, \mathrm{SO}_{2}, \mathrm{HCHO}\right),<20 \%$ for $\mathrm{CO}$ measurements in the thermal infra red (TIR) increasing to $40-60 \%$ in the visible $\left(\mathrm{NO}_{2}\right)$ (Martin, 2008). $\mathrm{NO}_{2}$ is well suited for studying urban pollution because of its short lifetime, the high source strength compared to the background and relatively enhanced sensitivity. Indeed clear signature of city scale enhancements in $\mathrm{NO}_{2}$ and even their weekly variations have been studied using the space based observations (Beirle et al., 2003; Boersma et al., 2009). Even for $\mathrm{CO}$ with a longer lifetime and reduced sensitivity to the boundary layer, Clerbaux et al. (2008) have shown that some cities can be detected in the time averaged thermal IR retrievals from Measurements of Pollution in the Troposphere (MOPITT), if the thermal contrast is high and the city pollution is trapped by nearby

Published by Copernicus Publications on behalf of the European Geosciences Union. 
mountains. Some city signatures in $\mathrm{CO}$ were also observed over India (Kar et al., 2008). $\mathrm{NO}_{2}$ and $\mathrm{CO}$ are both precursors of ozone, which is the primary component of smog and directly affects the health of humans and the ecosystem. However, detection of ozone signature for cities using the tropospheric column data is more difficult because only about $10 \%$ of the total ozone column resides in the troposphere. As such, urban scale enhancements in ozone from satellites have so far been explored only in a few cases (Shim et al., 2008; Eremenko et al., 2008). In this paper, we address the question if any possible signature of cities can be detected in the existing satellite ozone data. In previous studies using tropospheric ozone residuals from TOMS/SBUV measurements, the regional nature of ozone pollution has been identified and related to the interannual variability of El Niño in northeast India (Fishman and Balok, 1999; Fishman et al., 2003, 2005) and to crop productivity in the Midwestern US (Fishman et al., 2010). Although the use of these instruments was not intended to observe such small-scale tropospheric features, it is apparent from these studies that clear lower atmospheric signals are present in these datasets. This study expands on these findings by concentrating on even smaller scale studies to explore the potential utility of such measurements for studying urban-scale features. Such a study is critical for determining whether or not the current observational techniques might meet the needs of future instruments on a geostationary platform.

\section{Data}

The primary technique employed to obtain the tropospheric ozone column from satellite measurements is to subtract the stratospheric column ozone (SCO) from the concurrent total ozone column measured by a TOMS like instrument and over the years several such products have become available (Fishman et al., 1990, 2003; Ziemke et al., 2006; Schoeberl et al., 2007). We have used the data products derived using two of these methods. In the empirically corrected tropospheric ozone residuals (TOR), the SCO is determined by an empirical correction applied to the tropospheric profile as retrieved by the SBUV measurements and subsequently the resulting SCO is subtracted from the TOMS total column measurements (Fishman and Balok, 1999). Monthly mean fields of TOR are available and encompass the time period from 1979-2005 with missing data for the years 1994-1996. We also use the tropospheric column ozone (TCO) database derived by Ziemke et al. (2006) from the OMI and MLS instruments after cross calibrating the MLS SCO with OMI SCO obtained by the convective cloud differential method. These data have similar spatial resolution as the TOR data $\left(1^{\circ} \times 1.25^{\circ}\right)$ and are available from October 2004 onwards as monthly means. We also use tropospheric column abundances of $\mathrm{NO}_{2}$ retrieved by the Differential Optical Absorption Spectroscopy (DOAS) algorithm from SCIAMACHY measurements (Richter et al., 2005) as well as the OMI level 2 data for total ozone and efficiency factor. The wind data have been taken from the National Centers for Environmental Prediction (NCEP) reanalyses. The surface ozone data were obtained from the California Air Resources Board website.

\section{Results}

\subsection{Urban signatures in TOR and TCO data}

The empirically corrected TOR data delineated high tropospheric ozone in regions of the globe with high population densities like the Indo Gangetic basin, Eastern China and Eastern USA (Fishman et al., 2003). This delineation was possible because of the high spatial resolution afforded by that technique using the TOMS/SBUV measurements. In fact Fishman et al. (2003) had also reported a distinct plume from the Sao Paulo - Rio de Janeiro urban region. Figure 1 shows some examples of possible urban plumes detected in the tropospheric ozone residual data. The upper panels show the TOR distribution in the vicinity of Beijing (August 2005), New York (July 2005), Sao Paulo (October 2005) and Mexico City (February 2005). In the lower panels, the same cities are shown in the TCO data. Enhanced tropospheric ozone observed simultaneously in both the datasets indicates that the plumes may be associated with the cities and not artifacts of the retrieval. Note that the upper limit of the color scale has been changed for each city in order to clearly delineate the plumes. Except for Sao Paulo, the other cities show stronger plumes in the TOR data than in the TCO data and generally show similar orientation of the plumes. The winds shown in the plots correspond to $850 \mathrm{hPa}$ for Beijing, New York and Sao Paulo and $700 \mathrm{hPa}$ for Mexico City. For Beijing the winds are rather weak in August 2005 which would tend to promote ozone photochemistry. For New York City, the orientation of the ozone plume is consistent with the prevailing westerlies and extends over the Atlantic Ocean. Ozone plumes extending north east to Massachusetts and Maine originating from the New York plume in summer have been reported from air craft measurements (Sillman et al., 1993, Spicer et al., 1979). In general, the plumes at all the cities are quite extended. The typical lifetime of ozone in the troposphere is about 2-5 days in the boundary layer and increases to about 90 days in the middle troposphere. Ozone plumes associated with cities have been observed hundreds of $\mathrm{kms}$ away, from in-situ measurements and are generally understood as the result of photochemical production downwind from a city (Sillman et al., 1993, Goncalves et al., 2009 etc.). In particular, note that both TOR and TCO values are lower directly over Mexico City and a strong outflow plume following the wind direction can be seen to the north east of the city extending into the Gulf of Mexico. The low column ozone directly over the city is likely due to the high elevation of the city which is surrounded by mountain ridges on 

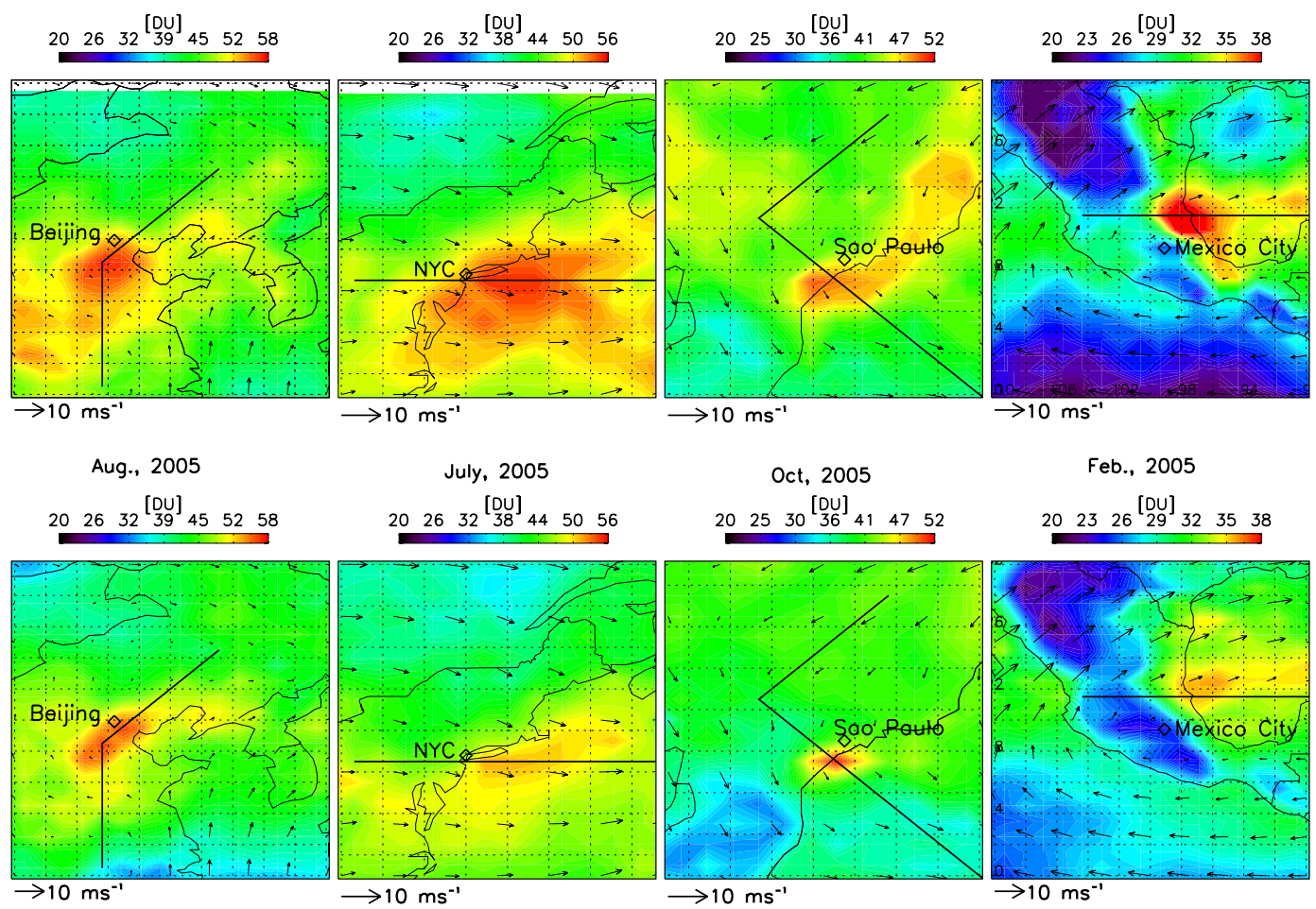

Fig. 1. Examples of urban scale signatures of tropospheric ozone pollution in monthly mean TOR (upper panels) and TCO data (lower panels) for Beijing (August 2005), New York (July 2005), Sao Paulo (October 2005) and Mexico City (February 2005). Note that the upper limits of the color scales have been changed for each city to optimize the detection of the individual plumes because of different pollution levels in various cities. The monthly mean winds (at $850 \mathrm{hPa}$ for Beijing, New York, Sao Paulo and at $700 \mathrm{hPa}$ for Mexico City) are from the NCEP reanalyses. The black lines indicate the grid cells along which the upstream/downstream TOR/TCO values were compared in Fig. 2.
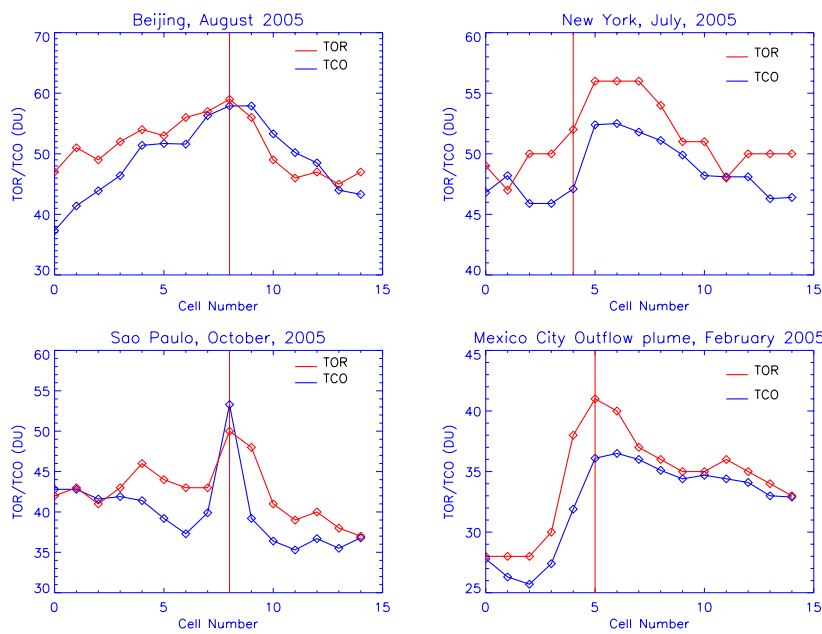

Fig. 2. Comparison of the upstream and downstream TOR/TCO values for the 4 urban plume examples shown in Fig. 1. The TOR and TCO values were sampled along the black lines shown in Fig. 1. The vertical red line indicates the position of the grid cell closest to the city. Note the vertical scales are different in each case. three sides and has a broad opening to the north. Low values of TOR over mountains and other elevated regions have been observed earlier in the empirically corrected TOR data (Fishman et al., 2003). This outflow plume to the north-east of the city has been observed persistently for various months and years of observation in the TOR as well as TCO data. In particular, the location of the outflow plume is quite similar to the aged or secondary Mexico City plume as observed by the in-situ aircrafts during March 2006 under the Megacities Initiative: Local and Global Research Observations (MILAGRO) campaign (Shim et al., 2009, Mena-Carrasco et al., 2009). The simulations of Mexico City outflow indicates that the ozone production could be about 6 times more efficient in the aged plume than in the young plume near the city (Tie et al., 2009). The city ozone anomaly is about 10 Dobson Units (DU; 1 DU $\equiv 2.69 \times 10^{16}$ molecules per $\mathrm{cm}^{2}$ ) in TOR distribution compared to the background for Beijing, New York and Sao Paulo and 5-6 DU for the Mexico City outflow plume.

Figure 2 shows a comparison between the upstream and downstream values of TOR/TCO for the 4 city plume examples shown in Fig. 1. The TOR/TCO values were sampled along the lines shown in black in Fig. 1 roughly following the wind directions near the 4 cities. The vertical red line indicates the grid cell closest to the city location. 
Thus the TOR/TCO values to the left of this line denote the upstream values and the ones to the right denote the downstream values. The TOR and TCO pictures show generally similar behavior although with different amplitudes. There are significant and interesting differences among the cities. The maximum upstream/downstream difference can be seen for the Mexico City outflow plume with the TOR/TCO values increasing sharply near the city and downstream TOR/TCO values remaining $\sim 5-7$ DU larger than the upstream values for several hundred kms. This indicates the significant regional influence of the Mexico City pollution as has been observed also from aircraft observations. A similar extended plume can be seen for the New York City, the downstream TOR/TCO values differing from the upstream values by $\sim 5$ DU. In contrast, the TOR/TCO values near Sao Paulo for October 2005 abruptly rise to very high values compared to the upstream values and seem to be contained within the vicinity of the city itself. Beijing also shows a less extended plume because of low wind speeds and a slow build up probably as a result of generally high ozone values in the upstream regions of Eastern China. This exercise shows the different scenarios that might be expected for urban ozone plumes from future satellite missions depending upon the strength and extent of the plume as well as regional influences.

It is important to consider the uncertainties involved in the detection of these urban plumes from the satellite derived residual ozone columns. Since we are interested in capturing the difference in the ozone levels between the plume and the background, it is the precision with which the tropospheric columns are determined that is more important than the accuracy or absolute error in the calculated amounts. Such biases are assumed to exhibit relatively little variability in the vicinity of the city. For TCO obtained from OMI/MLS, a precision uncertainty of about $5 \mathrm{DU}$ in the daily gridded data $\left(1^{\circ} \times 1.25^{\circ}\right)$ has been estimated from comparisons of stratospheric column ozone between Aura MLS and OMI (convective cloud differential method in the Pacific) and tropospheric ozone from sondes (Ziemke et al., 2006). The uncertainty in the monthly mean gridded data employed here decreases (by $1 / \sqrt{ } \mathrm{n}$, where $\mathrm{n}$ is the number of measurements per month) to $\sim 1$ DU after considering missing data from the cloud filtering. This uncertainty is small compared to the urban TCO anomalies of $\sim 5-10 \mathrm{DU}$. A similar estimate for the precision of the empirically corrected TOR methodology (Fishman et al., 2003) can be assumed. In addition, Fishman et al. (2003) presented a case study in which $\sim 83 \%$ of the enhancement from a pollution episode could be captured by the TOR methodology.

Figure 3 shows the corresponding urban plumes at the 4 cities as observed in the tropospheric column $\mathrm{NO}_{2}$ retrievals from the SCIAMACHY instrument for the same months. The $\mathrm{NO}_{2}$ columns are more sensitive to the boundary layer and the city plumes are observed in the immediate vicinity of the urban centers because of the low lifetime of $\mathrm{NO}_{2}(\sim$ hours to days depending upon the altitude, location and sea-
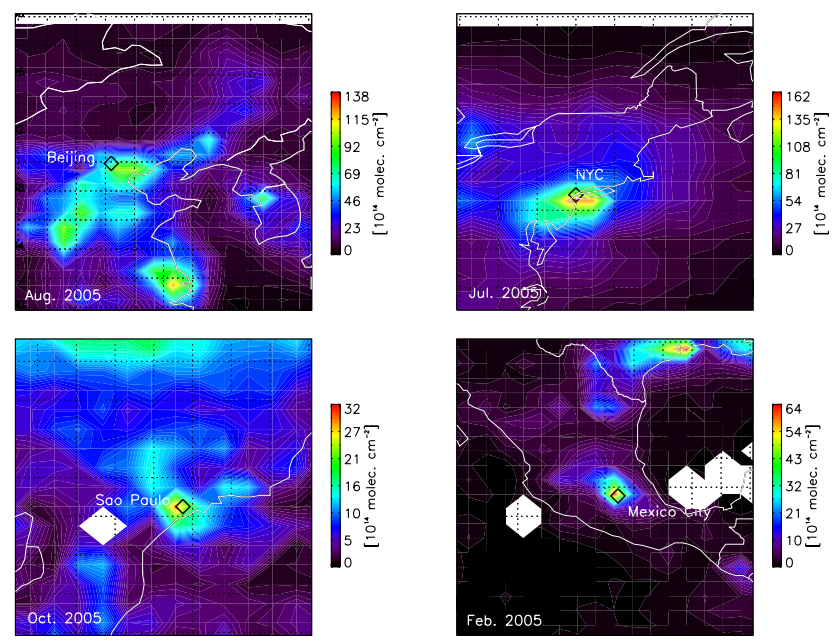

Fig. 3. The city plumes as observed in the SCIAMACHY tropospheric $\mathrm{NO}_{2}$ columns for the same months as in Fig. 1. As in Fig. 1, the upper limit of the color scales has been varied to bring out the city plumes more clearly.

son). The precision uncertainty of monthly averaged $\mathrm{NO}_{2}$ columns from SCIAMACHY has been estimated to be less than $5 \times 10^{14} \mathrm{~mol} \mathrm{~cm}^{-2}$ (Richter et al., 2005) which is much smaller than the urban $\mathrm{NO}_{2}$ column anomalies seen here. However, spatial variations in airmass factor may introduce additional uncertainty in the vicinity of strong sources. Note the general correspondence between the tropospheric ozone and $\mathrm{NO}_{2}$ column plumes as well as the much larger maximum values in both species for Beijing and New York. The coincident enhancements of $\mathrm{NO}_{2}$ with the ozone plumes support the premise that both the TOR and TCO spatial anomalies are indeed city ozone plumes.

We have used the same upstream/downstream transects as shown in Fig. 1 to study the correlation between TOR/TCO and $\mathrm{NO}_{2}$ tropospheric columns. Figure 4 shows this correlation using all the sampled data for the 4 cities taken together. As can be seen, there is a distinct positive correlation between the ozone and $\mathrm{NO}_{2}$ columns with a linear correlation coefficient of about 0.6 . If we use only the downstream points for each city, then the correlation coefficient increases to 0.7 . Note that these are monthly averaged values obtained from two different platforms. The correlation between the tropospheric columns of the two species likely depends upon whether the ozone production is $\mathrm{NO}_{\mathrm{x}}$ limited or VOC limited and this can vary significantly from city to city and also possibly from event to event. Thus Sillman et al. (1993) in their simulations found the slopes of the $\mathrm{O}_{3}-\mathrm{NO}_{\mathrm{y}}$ curves to be different for plumes related to New York-Connecticut, Boston-Maine and over Lake Michigan. In particular for New York city outflow plumes which were observed $\sim 110 \mathrm{~km}$ downwind of the city, Kleinman et al. (2000) found a ratio of $\mathrm{NO}_{\mathrm{x}} / \mathrm{NO}_{\mathrm{y}}$ of about 0.2-0.3 implying that much of the $\mathrm{NO}_{\mathrm{x}}$ had been consumed in the plume 

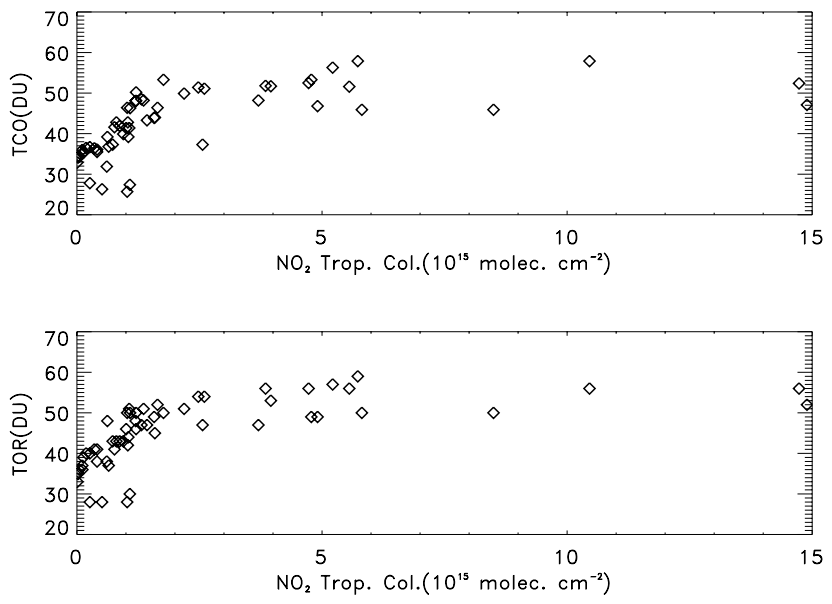

Fig. 4. Correlation between the TOR/TCO values and the corresponding $\mathrm{NO}_{2}$ tropospheric columns from SCIAMACHY. All the data from the upstream and downstream transects from the 4 city examples shown in Fig. 1 have been plotted together.

which had aged by about $3-4 \mathrm{~h}$. The peak $\mathrm{NO}_{\mathrm{x}}$ concentration of $\sim 7$ ppbv however was sufficient for active photochemistry in a VOC-sensitive regime leading to an ozone concentration of 100 ppbv. For Mexico City, Tie et al. (2009) found the aged outflow plume to be strongly $\mathrm{NO}_{\mathrm{x}}$ sensitive, while the plume is VOC-sensitive near the city. In addition, the correlation will also depend upon the meteorological conditions given the different lifetimes of the two species.

\subsection{OMI layer efficiency}

The capability to detect significant ozone anomalies in the lower troposphere from the residual ozone technique should be linked to the vertical sensitivity of the total ozone column retrievals from the TOMS or OMI measurements. The latter has been quantified in terms of an "efficiency factor" and is reported in the level 2 data products of TOMS (version 8) and OMI. In this scheme the best ozone column retrieved is formulated as

Best ozone $=\Sigma_{j=1}^{11} E_{j} x_{j}+\left(1-E_{j}\right) a_{j}$

where $E$ is the efficiency factor, $x$ is the true ozone profile and $a$ is the a priori ozone profile. The efficiency factor is reported in the TOMS/OMI level 2 products as "layer efficiency" at 11 levels corresponding to the mid points of the Umkehr layers (at 2.8, 7.9, 12.5, 17.0, 21.3, 25.8, 30.4, 35.2, $40.2,45.5,51.0 \mathrm{~km})$ and represents the sensitivity of the total ozone column to perturbations in a particular layer.

Figure 5 shows the monthly mean profiles of the OMI layer efficiency near Beijing (August 2005), New York (July 2005), Sao Paulo (October 2005) and Mexico City outflow plume (February 2005) up to $20 \mathrm{~km}$ as obtained from the OMI level 2 database for nearly cloud free conditions (reflectivity $<0.3$ ). Note that at $2.8 \mathrm{~km}$, the layer efficiency is

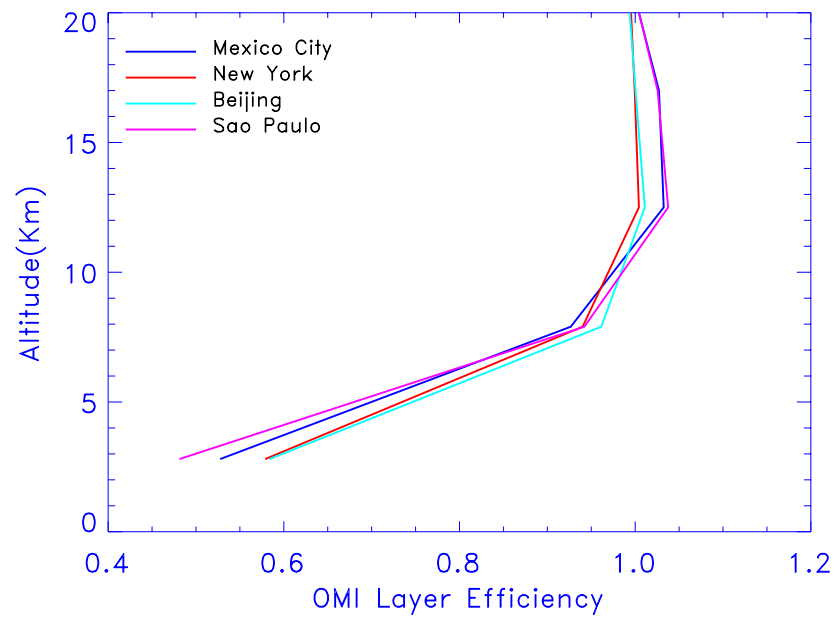

Fig. 5. Layer efficiency profiles near New York (July 2005), Beijing (August 2005), Sao Paulo (October 2005) and Mexico City outflow plume (February 2005) from the OMI level 2 data for reflectivity less than 0.3 .

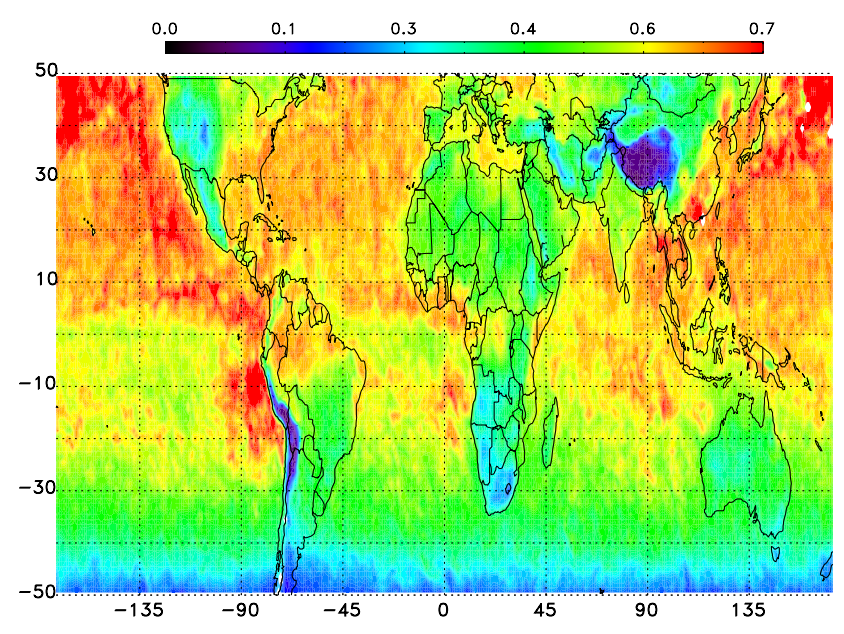

Fig. 6. Global distribution of the layer efficiency at $2.8 \mathrm{~km}$ for June 2005 from OMI level 2 data for reflectivity less than 0.3 . Only the pixel numbers 20 to 40 from each swath were used.

near 0.5-0.6 with highest values for Beijing and New York. These values may not be negligible, particularly for cities with strong ozone pollution compared to the surrounding areas. Ozone formation often takes place in the upper levels within the planetary boundary layer (PBL) (Goncalves et al., 2009) and the PBL height should be an important factor for sensing the low altitude pollution, with higher PBL heights in summer giving access to the low altitude information. The layer efficiency increases sharply to about 0.8 by $6 \mathrm{~km}$ and local convection may also loft the low altitude pollution higher up making the urban pollution amenable to detection by a TOMS/OMI like instrument. Figure 6 shows the global distribution of the layer efficiency at $2.8 \mathrm{~km}$ for the month of June 2005 from OMI retrievals for that month. We have used 
only the near nadir pixels (pixel numbers 20 to 40 from each swath) and reflectivity less than 0.3 (nearly cloud free) for this plot. As can be seen, the layer efficiency at $2.8 \mathrm{~km}$ can be near 0.6-0.7 over parts of China, Eastern USA and India with low values over mostly mountain areas. It should be mentioned that TCO data from OMI/MLS have been filtered for clouds and only pixels with reflectivity less than 0.3 have been used for their derivation (Ziemke et al., 2006), although this was not done for the TOR database. We have further examined the total ozone columns from OMI for the examples shown in Fig. 1 and found that clear signatures of the city plumes could be seen in the total ozone columns for Beijing, Sao Paulo and Mexico City and they were not affected by cloud filtering. The a priori ozone fields employed in the OMI retrievals were also quite zonal around cities and are unlikely to affect the results.

The efficiency factors in TOMS data are analogous to the total column averaging kernels. Liu et al. (2005) have retrieved ozone profiles as partial column ozone in the Umkehr layers from Global Ozone Monitoring Experiment (GOME) radiance measurements. The averaging kernels for these profiles at $3 \mathrm{~km}$ indicate strong sensitivity near the surface for the tropics (their Fig. 3). Liu et al. (2010) have recently retrieved ozone profiles from OMI measurements which indicate sensitivity down to $800-900 \mathrm{hPa}$ range. Other works also indicate that residual tropospheric columns using OMI measurements may provide information about ozone in the 900-650 hPa levels (Chatfield et al., 2008a, b). Thus it appears that UV instruments like TOMS and OMI may indeed have useful sensitivity to the lower tropospheric information contrary to the currently held view which may explain the observation of the urban scale signature in the TOR/TCO distributions as shown above. While we have detected these urban plumes in either TOR or TCO data for many other cities not shown here, they show up sporadically and not for all times at any particular city. A number of factors could be responsible for this, including stratospheric variability masking tropospheric signatures as well as stratosphere-to-troposphere exchange (STE) processes at mid to high latitudes, merging of plumes from nearby cities in generally polluted regions, sensitivity variations with season, local topography and meteorology. Further, a city downwind from a major biomass burning region may have large free tropospheric ozone which might again swamp the city signature, as was noted also for CO signature of cities (Clerbaux et al., 2008). On the other hand, isolated cities away from polluted continents may have better chances of detection, as was indeed observed with often clear signals at Jakarta, Colombo, Taipei etc. (not shown).

\subsection{Urban signatures in ozone VMR data}

As noted above for Mexico City, the elevated topography in several cases may inhibit observations of the urban plumes in TOR/TCO in the close vicinity of the cities themselves. The
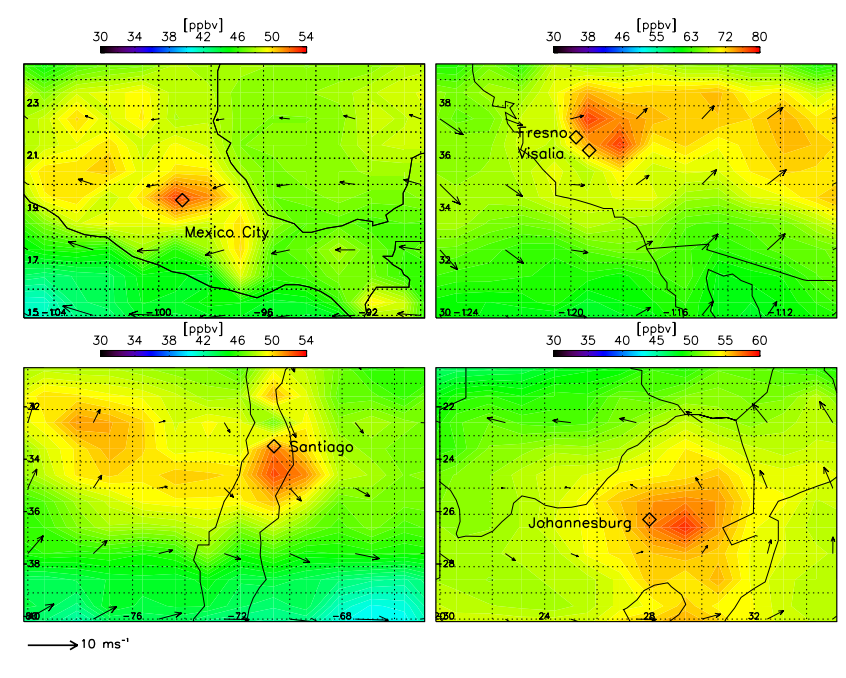

Fig. 7. Signatures of Mexico City (September), Fresno and Visalia (June), Santiago (February) and Johannesburg (January) in the climatological mean (2004-2008) tropospheric ozone VMR normalized for pressure variations at the surface and the tropopause. The NCEP reanalyses winds at $700 \mathrm{hPa}$ are averaged for the corresponding months between 2004-2008.

pressure variation both at the surface and the tropopause may affect the TOR/TCO calculations. Ziemke et al. $(2001,2006)$ have corrected for this by defining a pressure-averaged quantity to represent the tropospheric ozone. They use the following formula to obtain a mean tropospheric volume mixing ratio (VMR, in ppmv):

MeanVMR $=1.27\left(\mathrm{TCO} /\left(P_{\text {surface }}-P_{\text {tropopause }}\right)\right)$

where TCO is in DU and $P$ is in hPa. We have used this mean VMR data product, which is also available along with the TCO data from the OMI/MLS method. The use of mean VMR rather than the column data is likely to impact primarily signals from those cities which are in the vicinity of mountains. Figure 7 shows a few examples of urban signatures in climatological depictions averaged for the years (2004-2008) of available OMI/MLS measurements. For the mean ozone VMR from OMI/MLS, a precision uncertainty of $10 \mathrm{ppbv}$ is estimated for the daily gridded $\left(1^{\circ} \times 1.25^{\circ}\right)$ values decreasing to about $2.2 \mathrm{ppbv}$ for monthly means and to about $1 \mathrm{ppbv}$ for the 5 year climatologies presented here. As for TCO and TOR data, this uncertainty is small compared to the VMR anomalies near the cities ( $\sim-10 \mathrm{ppbv})$ thus lending credence to these detections.

As can be seen in Fig. 7, the maximum in the VMR plume is seen essentially centered on the location of Mexico City (September climatology, top left panel). A distinct signature of Mexico City was observed in the VMR data for many months with available data as was also the case for TOR or TCO data for this city. The upper right panel shows two distinct but close plumes near the cities of Fresno and Visalia 


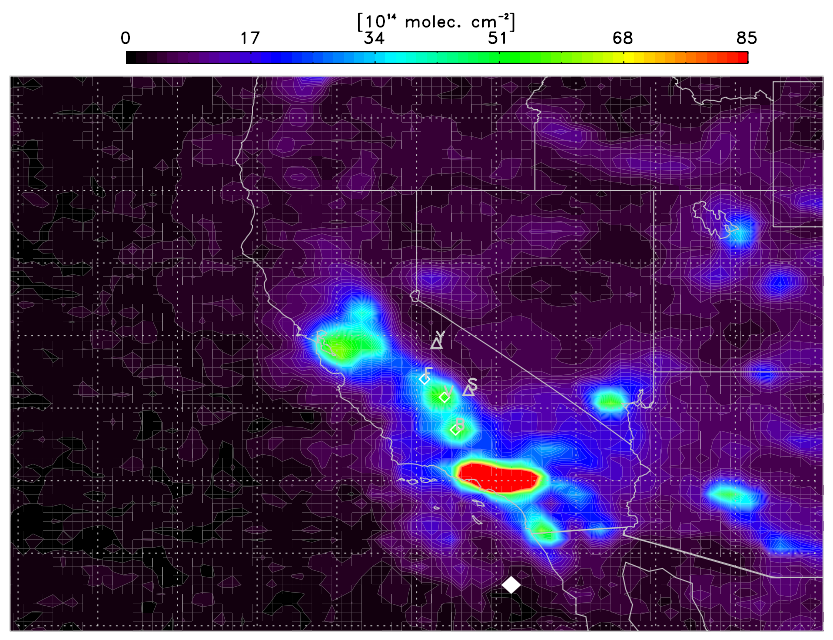

Fig. 8. Climatological (2005-2008) tropospheric $\mathrm{NO}_{2}$ columns for the month of June along the west coast of the USA. The location of the cities along the San Joaquin valley are shown as diamonds ( F Fresno, V - Visalia and B - Bakersfield) and the national parks are shown as triangles ( $\mathrm{Y}$ - Yosemite and $\mathrm{S}$ - Sequoia).

in the San Joaquin valley with rather high mean VMR values near $80 \mathrm{ppbv}$ (June climatology). Similar plumes were observed in the climatological mean VMR data in July and August as well and are thus likely to be robust features and are consistent with reports of high ozone pollution in the San Joaquin valley in California. The maximum of the plume near Fresno appears to be centered over the Yosemite National Park while the maximum of the plume near Visalia occurs over the Sequoia National Park. This is consistent with reports of high ozone levels in Yosemite National Park (e.g. Clements et al., 2004). On clear summer days upslope flows can transport the valley pollution over the Sierra Nevada as has been observed over Alpine valleys as well as over the Zagros mountains in the Middle East (Henne et al., 2004, Kar et al., 2006). Langford et al. (2010) have recently detected ozone plumes ( $\sim 100 \mathrm{ppbv})$ at $4 \mathrm{~km}$ by air borne lidar measurements over the San Gabriel mountains which originated in the Los Angeles basin and were lifted by topographic venting with subsequent long range transport. A similar mechanism might be consistent with the satellite depiction of ozone VMR near Yosemite and Sequoia in summer. The Johannesburg and Santiago plumes were also observed for several other months (lower right panel). The Johannesburg and Mexico City plumes in particular have also been observed in CO (Clerbaux et al., 2008).

Figure 8 shows the tropospheric $\mathrm{NO}_{2}$ columns from SCIAMACHY over the west coast of USA averaged over the years 2005-2008 for the month of June. In general high values can be seen along the San Joaquin valley with distinct plumes near Fresno/Visalia area, Bakersfield and stronger plumes in the San Francisco Bay area and Los Angeles. Given the proximity of Fresno/Visalia to the Yosemite and Sequoia Na-

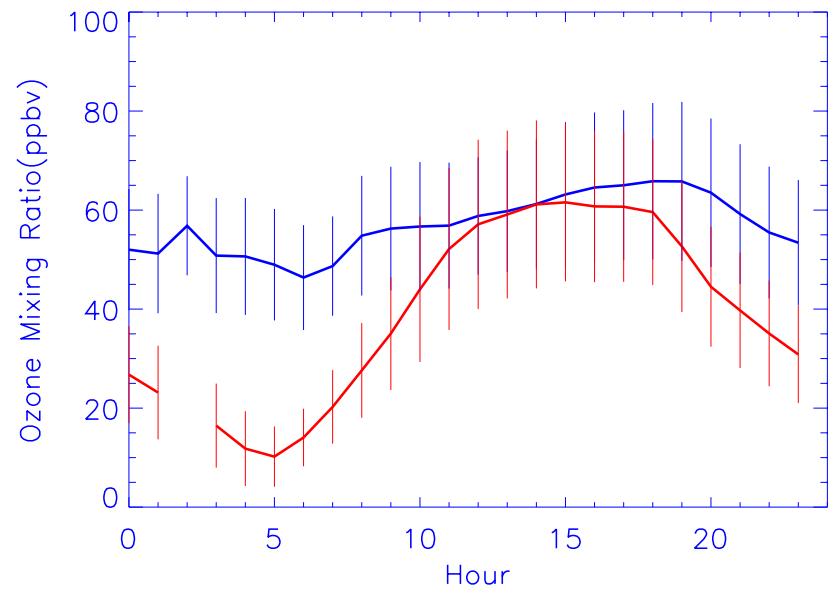

Fig. 9. Climatological (2005-2008) diurnal cycles of surface ozone mixing ratios at Fresno (Red) and Turtleback dome (Blue) in Yosemite National Park for the month of June.

tional Parks and the prevailing westerly winds, it is likely that photochemical ozone production in aged urban plumes from these cities will impact these parks. Using back trajectories, Burley and Ray (2007) have shown that air reaching Yosemite often originate in the Bay area but most of the pollution is injected into the plumes as they traverse the Central Valley. Apart from the urban plumes from the Bay area and the San Joaquin valley, ozone levels at Yosemite and Sequoia are also likely to be affected by regional biomass burning in summer. A proper investigation of the source of high ozone VMR over Yosemite and Sequoia would require high resolution regional scale modeling including topographic venting.

It is interesting to compare these results from satellite tropospheric ozone columns with the ozone levels at the surface, although the relationship may not be straightforward (Fishman et al., 2003). Fresno and Visalia figure just below Los Angeles and Bakersfield in the list of US cities with highest ozone pollution at the surface level (http://www.stateoftheair. org/2010/city-rankings/most-polluted-cities.html). Figure 9 shows the climatological diurnal variations in ozone mixing ratio (averaged over the years 2005-2008 for June) at the surface from two stations, at Fresno (station no 2013) and at the Turtleback dome (station no 3018) in Yosemite National Park. The average ozone mixing ratios are higher at Turtleback dome for much of the day. There is considerable variability in the ozone levels at both the stations with maximum values sometimes exceeding $100 \mathrm{ppb}$. The lack of a significant diurnal variation at the Turtleback dome could be due to the local topography (Burley and Ray, 2007). The correlation coefficient between the ozone levels at the two stations during June 2005-2008 increases sharply from low values $(<0.5)$ at night and midmorning hours to $\sim 0.7-0.8$ between 01:00 p.m. and 08:00 p.m. suggesting the impact of the Fresno plume on Yosemite during these hours. Clements et al. (2004) had also observed very high values ( $\sim 110 \mathrm{ppbv})$ 

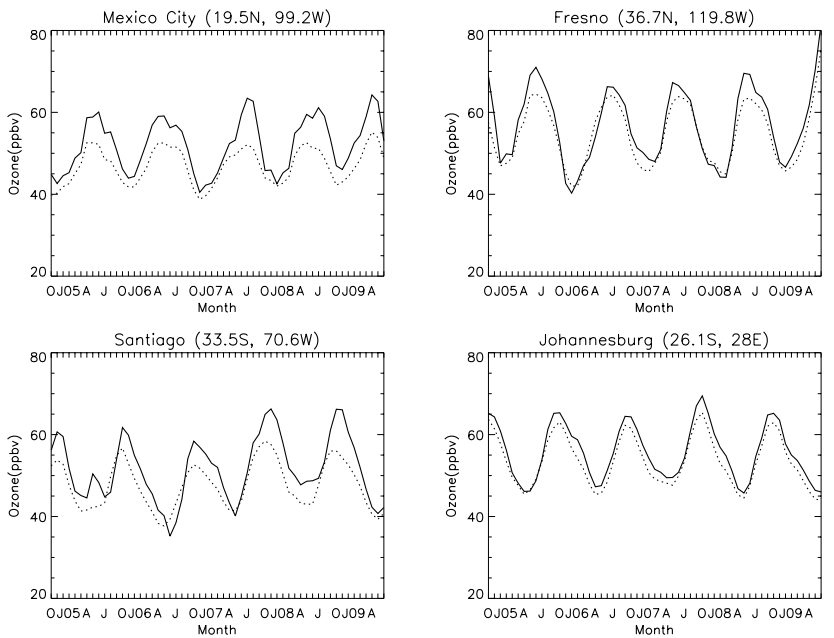

Fig. 10. Time series of monthly mean tropospheric ozone VMR at the 4 cities shown in Fig. 7 (solid lines) along with corresponding time series averaged over $\pm 5^{\circ}$ in latitude and longitude around the city grid cell (dashed lines)( 3 month running average).

at Turtleback dome and Tioga Pass ( $80 \mathrm{ppbv}$, at $3029 \mathrm{~m}$ above mean sea level) on 19 August 2003 and attributed that to transport from the San Joaquin valley. The tropospheric column ozone and thus the mean ozone VMR over these areas will depend upon the shape of the ozone mixing ratio profile which will in turn depend upon vertical mixing at these locations.

In order to study the signature of the city plume as a function of time, we need to compare the ozone VMR time series at the city with that at an upstream location. However the wind direction at any city changes with season. Therefore we take the average ozone VMR over $\pm 5^{\circ}$ in latitude and longitude around the city grid cell (excluding the grid cell containing the city itself) as the background value of the ozone VMR in the vicinity of the city, although it might contain the contributions from the outflow plumes from the city at certain times. Further, taking this average over too large an area might include contributions from other urban centers. Figure 10 shows these two time series at Mexico City, Fresno, Santiago and Johannesburg for the period of OMI data (2004-2009). For Mexico City and Santiago, an ozone anomaly over the city can be seen in most months of the year with somewhat higher values in local summer as might be expected from enhanced photochemistry. Over Fresno the enhancement is seen primarily in summer and the anomaly over Johannesburg is lower than in the other cities. The latter may partly be attributed to the fact that in summer, the mid tropospheric ozone peak over Johannesburg is due to long range transport of air from Central Africa (Diab et al., 2003). As for TOR and TCO, signatures of several other cities around the globe could be detected, albeit sporadically, in the VMR database.

\section{Conclusions}

In this paper, we addressed the question of detecting possible signatures of cities in the tropospheric ozone columns for the first time as it should have important implications for future geostationary missions. It was found that city signatures could indeed be detected in the TOR, TCO as well as mean tropospheric VMR data bases as enhanced ozone plumes with general similarity to corresponding $\mathrm{NO}_{2}$ tropospheric column plumes. An interesting result was the high mean ozone VMR plumes observed over the Yosemite and Sequoia National Parks in summer possibly resulting from the urban plumes of Fresno and Visalia and the San Francisco Bay area. An analysis of the OMI retrieval layer efficiencies indicated a fair degree of sensitivity to the lower troposphere which along with lifting of the boundary layer pollution by convection or topographic venting could possibly explain these features. However a caveat is that these plumes were observed mostly sporadically and not at all times. These results should have interesting implications for satellite remote sensing of urban pollution. Further investigation is needed to understand the various factors influencing the detection of these plumes and to characterize them using data on other concurrent trace species.

Acknowledgements. J. K. is grateful to P. K. Bhartia and Jim Crawford for useful discussions and to Malcolm Ko for support. We thank the Air Resources Board of California for making available the ground based ozone data through their website and the referees for helpful comments which improved the quality of the paper.

Edited by: M. Van Roozendael

\section{References}

Beirle, S., Platt, U., Wenig, M., and Wagner, T.: Weekly cycle of NO2 by GOME measurements: a signature of anthropogenic sources, Atmos. Chem. Phys., 3, 2225-2232, doi:10.5194/acp3-2225-2003, 2003.

Boersma, K. F., Jacob, D. J., Trainic, M., Rudich, Y., DeSmedt, I., Dirksen, R., and Eskes, H. J.: Validation of urban $\mathrm{NO}_{2}$ concentrations and their diurnal and seasonal variations observed from the SCIAMACHY and OMI sensors using in situ surface measurements in Israeli cities, Atmos. Chem. Phys., 9, 3867-3879, doi:10.5194/acp-9-3867-2009, 2009.

Burley, J. D. and Ray, J. D., Surface ozone in Yosemite National Park, Atmos. Environ., 41, 6048-6062, 2007.

Chatfield, R., Schoeberl. M., Stajner, I., Wargan, K., Oltmans, S., and Thompson, A.: Evaluation of lower tropospheric ozone estimates based on OMI and MLS for pollution studies and a California example, Eos Trans. AGU, 89(23), Jt. Assem. Suppl. Abstract A23A-04, 2008a.

Chatfield, R., Bhartia, P. K., Schoeberl, M., Liu, X., Oltmans, S., Esswein, R., Tarasick, D., and Thompson, A. M.: How well do OMI's UV-based retrievals sample the lowermost troposphere, presented at the AURA science team meeting, Baltimore, 27-30 October, 2008b. 
Clerbaux, C., Edwards, D. P., Deeter, M., Emmons, L., Lamarque, J.-F., Tie, X. X., Massie, S. T., and Gille, J. C.: Carbon monoxide pollution from cities and urban areas observed by the Terra/MOPITT mission, Geophys. Res. Lett., 35, L03817, doi:10.1029/2007GL032300, 2008.

Clements, C. B., Zhong, S., Kim, S. B., Burley, J. D., High-altitude ozone concentrations in Yosemite National Park, Sierra Nevada, in: Proceedings of the 16th Conference on Air Pollution Meteorology, American Meterological Society, Vancouver, BC, 22-27 August, 2004.

Diab, R. D., Raghunandan, A., Thompson, A. M., and Thouret, V.: Classification of tropospheric ozone profiles over Johannesburg based on mozaic aircraft data, Atmos. Chem. Phys., 3, 713-723, doi:10.5194/acp-3-713-2003, 2003.

Duncan, B. N., West, J. J., Yoshida, Y., Fiore, A. M., and Ziemke, J. R.: The influence of European pollution on ozone in the Near East and northern Africa, Atmos. Chem. Phys., 8, 2267-2283, doi:10.5194/acp-8-2267-2008, 2008.

Eremenko, M., Dufour, G., Foret, G., Keim, C., Orphal, J., Beekmann, M., Bergametti, G., and Flaud, J.-M. Tropospheric ozone distributions over Europe during the heat wave in July 2007 observed from infrared nadir spectra recorded by IASI, Geophys. Res. Lett., 35, L18805, doi:10.1029/2008GL034803, 2008.

Fishman, J. and Balok, A. E.: Calculation of daily tropospheric ozone residuals using TOMS and empirically improved SBUV measurements: Application to an ozone pollution episode over the eastern United States, J. Geophys. Res., 104, 30319-30340, 1999.

Fishman, J., Watson, C. E., Larsen, J. C., and Logan, J. A.: Distribution of tropospheric ozone determined from satellite data, J. Geophys. Res., 95, 3599-3617, 1990.

Fishman, J., Brackett, V. G., Browell, E. V. and Grant, W. B.: Tropospheric ozone derived from TOMS/SBUV measurements during TRACE-A, J. Geophys. Res., 101(D19), 24069-24082, 1996.

Fishman, J., Wozniak, A. E., and Creilson, J. K.: Global distribution of tropospheric ozone from satellite measurements using the empirically corrected tropospheric ozone residual technique: Identification of the regional aspects of air pollution, Atmos. Chem. Phys., 3, 893-907, doi:10.5194/acp-3-893-2003, 2003.

Fishman, J., Creilson, J. K., Wozniak, A. E. and Crutzen, P. J.: Interannual variability of stratospheric and tropospheric ozone determined from satellite measurements, J. Geophys. Res., 110, D20306, doi;10.1029/2005JD005868, 2005.

Fishman, J., Bowman, K. W., Burrows, J. P., Richter, A., Chance, K. V., Edwards, D. P., Martin, R. V., Morris, G. A., Pierce, R. B., Ziemke, J. R., Al-Saadi, J. A., Creilson, J. K., Schaack, T. K., and Thompson, A. M.: Remote sensing of tropospheric pollution from space, B. Am. Meteor. Soc., 89, 805-821, 2008.

Fishman, J., Creilson, J. K., Parker, P. A., Ainsworth, E. A., Vining, G. G. and Szarka. J. L., Booker, F. L., and Xu, X.: An investigation of widespread ozone damage to the soybean crop in the upper Midwest determined from ground-based and satellite measurements, Atmos. Environ., 44, 2248-2256, 2010.

Gonçalves, M., Jiménez-Guerrero, P., and Baldasano, J. M.: Contribution of atmospheric processes affecting the dynamics of air pollution in South-Western Europe during a typical summertime photochemical episode, Atmos. Chem. Phys., 9, 849-864, doi:10.5194/acp-9-849-2009, 2009.
Gurjar, B. R., Butler, T. M., Lawrence, M. G., and Lelieveld, J.: Evaluation of emissions and air quality in megacities, Atmos. Environ., 42, 1593-1606, 2008.

Henne, S., Furger, M., Nyeki, S., Steinbacher, M., Neininger, B., de Wekker, S. F. J., Dommen, J., Spichtinger, N., Stohl, A. and Prevot, A. S. H.: Quantification of topographic venting of boundary layer air to the free troposphere, Atmos. Chem. Phys., 4, 497509, 2004, http://www.atmos-chem-phys.net/4/497/2004/.

Kar, J., Drummond, J. R., Jones, D. B. A., Liu, J., Nichitiu, F., Zou, J., Gille., J. C., Edwards, D. P., and Deeter, M. N.: Carbon monoxide (CO) maximum over the Zagros mountains in the Middle East: Signature of mountain venting?, Geophys. Res. Lett., 33, L15819, doi:10.1029/2006GL026231, 2006.

Kar, J., Jones, D. B. A., Drummond, J. R., Attie, J. L., Liu, J., Zou, J., Nichitiu, F., Seymour, M. D., Edwards, D. P., Deeter, M. N., Gille, J. C. and Richter, A.: Measurement of low altitude CO over the Indian subcontinent by MOPITT, J. Geophys. Res., 113, D16307, doi;10.1029/2007JD009362, 2008.

Kleinman, L. I., Daum, P. H., Imre, D. G., Lee, J. H., Lee, Y.N., Nunnermacker, J., Springston, S. R., Weinstein-Lloyd, J., and Neuman, L., Ozone production in the New York City urban plume, J. Geophys. Res., 105(D11), 14495-14511, 2000.

Langford, A. O., Senff, C. J., Alvarez II, R. J., Banta, R. M., and Hardesty, R. M.: Long-range transport of ozone from the Los Angeles Basin: A case study, Geophys. Res. Lett., 37, L06807, doi:10.1029/2010GL042507, 2010.

Liu, X., Chance, K., Sioris, C. E., Spurr, R. J. D., Kurosu, T. P., Martin, R. V., and Newchurch, M. J.: Ozone profile and tropospheric ozone retrievals from the Global Ozone Monitoring Experiment: Algorithm description and validation, J. Geophys. Res., 110, D20307, doi:10.1029/2005JD006240, 2005.

Liu, X., Bhartia, P. K., Chance, K., Spurr, R. J. D., and Kurosu, T. P.: Ozone profile retrievals from the Ozone Monitoring Instrument, Atmos. Chem. Phys., 10, 2521-2537, doi:10.5194/acp-10-25212010, 2010.

Martin, R. V.: Satellite remote sensing of surface air quality, Atmos. Environ., 42, 7823-7843, 2008.

Mena-Carrasco, M., Carmichael, G. R., Campbell, J. E., Zimmerman, D., Tang, Y., Adhikary, B., D'allura, A., Molina, L. T., Zavala, M., García, A., Flocke, F., Campos, T., Weinheimer, A. J., Shetter, R., Apel, E., Montzka, D. D., Knapp, D. J., and Zheng, W.: Assessing the regional impacts of Mexico City emissions on air quality and chemistry, Atmos. Chem. Phys., 9, 37313743, doi:10.5194/acp-9-3731-2009, 2009.

Molina, L. T., Kolb, C. E., de Foy, B., Lamb, B. K., Brune, W. H., Jimenez, J. L., Ramos-Villegas, R., Sarmiento, J., ParamoFigueroa, V. H., Cardenas, B., Gutierrez-Avedoy, V., and Molina, M. J.: Air quality in North America's most populous city overview of the MCMA-2003 campaign, Atmos. Chem. Phys., 7, 2447-2473, doi:10.5194/acp-7-2447-2007, 2007.

Richter, A., Burrows, J. P., Nub, H., Granier, C., and Niemeier, U.: Increase in tropospheric nitrogen dioxide over China observed from space, Nature, 437, 129-132, doi:10.1038/nature04092, 2005.

Schoeberl, M. R., Ziemke, J. R., Bojkov, B., Livesey, N., Duncan, B., Strahan, S., Froidevaux, L., Kulawik, S., Bhartia, P. K., Chandra, S., Levelt, P. F., Witte, J. C., Thompson, A.M., Cuevas, E., Redondas, A., Tarasick. D. W., Davies, J., Bodeker, G., Hansen, G., Johnson, B. J., Oltmans, S. J., Vomel, H., Allaart, M., Kelder, 
H., Newchurch, M., Godin-Beekmann, S., Ancellet, G., Claude, H., Andersen, S. B., Kyro, E., Parrondos, M., Yela, M., Zablocki, G., Moore, D., Dier, H., von der Gathen, P., Viatte, P., Stubi, R., Calpini, B., Skrivankova, P., Dorokhov, V., de Backer, H., Schmidlin, F. J., Coetzee, G., Fujiwara, M., Thouret, V., Posny, F., Morris, G., Merrill, J., Leong, C. P., Koenig-Langlo, G. and Joseph, E., A trajectory-based estimate of the tropospheric ozone column using the residual method, J. Geophys. Res., 112, D24S49, doi:10.1029/2007JD008773, 2007.

Sillman, S., Samson, P. J., and Masters, J. M.: Ozone production in urban plumes transported over water: Photochemical model and case studies in the northeastern and Midwestern United States, J. Geophys. Res., 98(D7), 12687-12699, 1993.

Shim, C., Li, Q., Luo, M., Kulawik, S., Worden, H., Worden, J., Eldering, A., Diskin, G., Sachse, G., Weinheimer, A., Knapp, D., Montzca, D., and Campos, T.: Satellite observations of Mexico City pollution outflow from the Tropospheric Emissions Spectrometer (TES), Atmos. Environ., 43, 1540-1547, 2009.
Spicer, C. W., Joseph, D. W., Sticksel, P. R. and Ward, G. F.: Ozone sources and transport in the North Eastern United States, Environ. Sci. Technol., 13, 975-985, 1979.

Tie, X., Madronich, S., Li, G., Ying, Z., Weinheimer, A., Apel, E., and Campos, T.: Simulation of Mexico City plumes during the MIRAGE-Mex field campaign using the WRF-Chem model, Atmos. Chem. Phys., 9, 4621-4638, doi:10.5194/acp-9-4621-2009, 2009.

Ziemke, J. R., Chandra, S. and Bhartia, P. K.: "Cloud slicing": A new technique to derive upper tropospheric ozone from satellite measurements, J. Geophys. Res., 106, 9853-9867, 2001.

Ziemke, J. R., Chandra, S., Duncan, B. N., Froidevaux, L., Bhartia, P. K., Levelt, P. F., and Waters, J. W.: Tropospheric ozone determined from Aura OMI and MLS: Evaluation of measurements and comparison with the Global Modeling Initiative's Chemical Transport Model, J. Geophys. Res., 111, D19303, doi:10.1029/2006JD007089, 2006. 